\title{
Strategi Public Relations Kementerian Pariwisata dan Ekonomi Kreatif dalam Membangun Media Relations
}

\author{
Elpa Hermawan \\ Universitas Bina Sarana Informatika Jakarta \\ elpa.ehn@bsi.ac.id
}

\begin{abstract}
The aims of study were to obtain in-depth information about public relations (PR) strategies from the Ministry of Tourism and Creative Economy in implementing media relations. Media relations is the main key in public relations to convey and control information to the public. Public relations require the media in achieving its goals. The research method was qualitative descriptive. Data is taken from the Ministry of Tourism and Creative Economy document. Data analysis consists of data reduction, data presentation, and drawing conclusions. The results of the study concluded that the Ministry of Tourism and Creative Economy has two media strategies namely the first POP (pre event, on event, post event). This strategy is carried out through a variety of interesting activities. Second is POSE (paid media, owned media, social media, endorsers). This strategy is quite effective in conveying information to the public about Indonesian tourism. From the implementation of the media, the Ministry of Tourism and Creative Economy received various awards. This also has an impact on increasing the interest of tourists to Indonesia both from domestic and abroad.
\end{abstract}

Keywords: Tourism, Public Relations, Media Relations

\begin{abstract}
Abstrak
Penelitian ini bertujuan untuk mendapatkan informasi mendalam tentang strategi public relations $(P R)$ dari Kementerian Pariwisata dan Ekonomi Kreatif dalam mengimplementasikan media relations. Media relations menjadi kunci utama dalam public relations untuk menyampaikan dan mengontrol informasi kepada masyarakat. PR membutuhkan media dalam mencapai tujuan. Metode penelitian adalah kualitatif deskriptif. Data diambil dari dokumen Kementerian Pariwisata dan Ekonomi Kreatif. Analisis data terdiri dari reduksi data, penyajian data, dan penarikan simpulan. Hasil penelitian menyimpulkan bahwa Kementerian Pariwisata dan Ekonomi Kreatif mempunyai dua strategi media yaitu pertama POP (Pre Event, On Event, Post Event). Strategi ini diselenggarakan melalui berbagai macam kegiatan yang menarik. Kedua adalah POSE (Paid Media, Owned Media, Social Media, Endorser). Strategi ini cukup efektif dalam menyampaikan informasi kepada masyarakat tentang pariwisata Indonesia. Dari implementasi media tersebut, Kementerian Pariwisata dan Ekonomi Kreatif mendapatkan berbagai penghargaan. Hal ini berdampak pula pada peningkatan minat wisatawan ke Indonesia baik dari dalam negeri maupun luar negeri.
\end{abstract}

Kata kunci: Pariwisata, Public Relations, Media Relations

Alamat korespondensi :

Jl. RS Fatmawati Blok Ry No. 24 Cilandak

Jakarta Selatan 12450 


\begin{tabular}{|c|c|}
\hline Permalink/DOI & : http://dx.doi.org/10.32503/jmk.v5i2.1028 \\
\hline Cara Mengutip & $\begin{array}{l}\text { Hermawan, Elpa. (2020). Strategi Public Relations Kementerian } \\
\text { Pariwisata dan Ekonomi Kreatif dalam Membangun Media } \\
\text { Relations. JMK (Jurnal Manajemen dan Kewirausahaan), } 5 \text { (2), } \\
\text { 140-154 doi: http://dx.doi.org/10.32503/jmk.v5i2.1028 }\end{array}$ \\
\hline Sejarah Artikel & $\begin{array}{l}\text { : Artikel diterima } 19 \text { April 2020; direvisi } 26 \text { April 2020; disetujui } \\
6 \text { Mei } 2020\end{array}$ \\
\hline
\end{tabular}

\section{Pendahuluan}

Kementerian Pariwisata dan Ekonomi Kreatif Indonesia selalu berupaya untuk meningkatkan sector pariwisata. Apalagi pariwisata di Indonesia banyak mempunyai keunggulan kompetitif dan komparatif. Berbagai strategi melalui media telah dipromosikan. Pemerintah telah membangun strategu dari aspek destinasi, pemasaran, dan sumber daya manusia, masyarakat dan industri. Setiap strategi telah diselaraskan dengan programprogram untuk meningkatkan daya tarik wisata Indonesia dan pemanfaatan teknologi (Hermawan, 2019). Berbagai tempat wisata telah melakukan strategi yang menarik untuk membangun kualitas pariwisata Indoensia. Seperti yang dilakukan oleh Achsa, Destiningsih and Hirawati (2020) berpendapat bahwa ada tiga prioritas strategi yang sangat penting dalam mengoptimalkan daya saing wisata seperti yang telah dilakukan di Taman Bunga Manohara. Ketiga strategi tersebut adalah mempertahankan kekhasan obyek wisata, mengoptimalkan lokasi obyek wisata, dan meningkatkan profesionalitas pengelolaan secara keseluruhan.

Maka dari itu, salah satu aspek yang sangat berperan dalam membangun pariwisata dan ekonomi Indonesia adalah sumber daya manusia, industri dan teknologi. Pemerintah beranggapan bahwa strategi public relations yang memanfaatkan media relations dapat meningkatkan produk pariwisata yang lebih kreatif atau banyak dikenal oleh masyarakat luar dan dalam negeri. Dengan adanya kemajuan teknologi dapat memudahkan media promosi pada masyarakat.

Banyak orang yang telah melek teknologi menjadi kemudahan bagi pemerintah dalam membangun citra pariwisata Indonesia, karena informasi pariwisata tidak hanya dapat diakses oleh masyarakat Indonesia, bahkan masyarakat mancanegara. Dalam hitungan detik segala informasi yang terbaru dapat diakses atau diketahui oleh masyarakat. Apalagi, saat ini marak media sosial yang telah digunakan oleh berbagai sektor ekonomi ataupun bisnis untuk memperkenalkan pariwisata ke masyakat. Jaringan internet yang sangat mudah menjadikan akses informasi tersebut lebih cepat diketahui oleh masyarakat.

Oleh karena itu, peran teknologi atau information digital telah memudahkan pemerintah dalam membangun kepercayaan masyarakat. 
Untuk memanfaatkan teknolgi, pemerintah melalui Kementerian Pariwisata dan Ekonomi Kreatif membangun strategi public relations yang berkaitan dengan media relations untuk meningkatkan pariwisata Indonesia. Dengan demikian, segala program yang telah direncanakan dapat terimplementasikan dengan baik. Persaingan global dalam dunia bisnis pariwisata mengharuskan pemerintah untuk merencanakan strategi public relations yang tepat sebagai media promosi. Media relations dapat menggunakan media massa atau media sosial yang saat ini cukup efektif dan viral dikalangan masyarakat.

Public relations membangun strategi-strategi yang tepat untuk mencapai tujuan, termasuk pada penggunaan media relations. Seperti yang dikatakan oleh Soleh and Elvinaro (2003) bahwa beberapa strategi public relation yang berkaitan dengan media adalah 1) strategi pelayanan kepada media massa yang dibutuhakan, 2) membangun kepercayaan, 3) memberikan informasi yang tepat, 4) membangun kerjasama yang baik dalam berbagi informasi, 5) menyediakan fasilitas, dan 6) membangun hubungan secara personal dengan media. Dari konsep pemahaman tersebut, strategi public relations memiliki keterkaitan erat dengan media relations dalam meningkatkan ketertarikan turis terhadap pariwisata di Indonesia.

Dari paparan tersebut dapat disimpulkan bahwa strategi public relations merupakan bagian yang sangat penting untuk meningkatkan daya tarik wisatawan, hingga penelitian ini dilakukan. Meskipun demikian, penelitian tentang public relations telah dibahas dalam penelitian sebelumnya. Pertama, penelitian tentang media massa menjadi media yang penting dalam menyampaikan pesan atau informasi kepada public, sehingga public relations dan media relations harus memiliki hubungan yang selaras (Hafizah, 2015). Kedua tentang salah satu strategi yang bisa dilakukan dalam public relations adalah strategi proaktif yang bisa diarahkan pada cara pemasaran iklan baik di koran, tabloid, rado, majalah, pamphlet, dan brosur (Solihah, Musiasa and Shihab, 2018). Ketiga Sedangkan lima aktivitas media relations untuk mempromosikan pariwisata daerah di Kabupaten Kutai Kertanegara yaitu press release, konferensi pers, special event, press interview, dan press tour (Febriandi, 2017).

Representasi strategis dan promosi pasar wisata global sangat penting untuk mencapai pesaing dalam pariwisata dan produk wisata di setiap negara. Perencanaan strategis, pembangunan, dan praktik Humas dalam industri pariwisata sangat penting karena proses menciptakan citra destinasi wisata tidak tergantikan tanpa adanya hubungan masyarakat yang dibuat dan diimplementasikan secara strategis (Ilievska, 2018). Dalam era teknologi, meda online menjadi sarana untuk public relations yang 
tidak dapat dihindarkan karena effektif dalam menyampaikan informasi. Seperti yang telah dibuktikan oleh Wiratmo, Irfan and Kuwatono (2017) bahwa setiap pemerintah daerah harus dapat memanfaatkan website yang mereka miliki sebagai sarana mengembangkan Online PR..

Akan tetapi, penelitianpenelitian tersebut belum membahas tentang strategi public relations untuk meningkatkan keberadaan media relations dalam dunia pariwisata lebih mendalam. Penelitian ini penting dilakukan karena beberapa alasan. Pertama tentang strategi public relations yang yang dilakukan oleh Kementerian Pariwisata dan Ekonomi Kreatif belum dikaji mendalam. Kedua strategi public relations menjadi bagian penting dalam media relations. Ketiga strategi terbaru yang telah dikembangkan oleh pemerintah Indonesia dalam meningkatkan kualitas pariwisata sesuai dengan perkembangan teknologi dan persaingan global.

Oleh karena itu, tujuan dari penelitian ini adalah untuk mengetahui strategi public relations yang digunakan oleh Kementerian Pariwisata dan Ekonomi Kreatif dalam membangun media relations. Dengan demikian, media relations memanfaatkan teknologi sesuai dengan kebutuhan saat ini melalui media massa dan media sosial. Fokus dalam kajian ini dilihat dari keragaman media yang digunakan Kementerian Pariwisata dan Ekonomi Kreatif Indonesia sebagai bagian dari implementasi strategi public relations, sehingga keberadaan pariwisata di Indonesia semakin maju dan mudah di kenal

\section{Tinjauan Pustaka}

Public relations memberikan pengaruh yang cukup baik terhadap perubahan sikap dan perbuatan masyarakat secara langsung dan tidak langsung dari keberadaan suatu produk. Public relations berperan sebagai media untuk berkomunikasi suatu organisasi atau destinasi wisata dengan pihak-pihak terkait untuk membangun suatu citra. Contoh pariwisata d Bali, dalam menghadapi tantangan maka peran public relations ditingkatkan seperti membangun konsolidasi dengan organisasiorganisasi pariwisata untuk membina hubungan dengan pemerintah. Dengan demikian, kebijakan pemerintah dalam mengembangkan pariwisatabisa memenuhi kebutuhan, harapan dan keinginan dari pelaku perusahaan pariwisata di Bali. Selain itu, kegiatan pengembangan sosial masyarakat melalui edukasi yang sangat baik (Putra, 2008). Dari kajian tersebut diketahui bahwa ada pendekatan yang berorientasi pada masyarakat.

Seperti yang dikatakan oleh Ruslan bahwa aspek strategi yang sering digunakan oleh praktisi public relations dalam mencapai tujuan, antara lain pendekatan kemasyarakatan, persuasive, dan edukasi sehingga tanggung jawab sosial dalam public relation dapat 
terpadu secara integratif. Jadi fungsi public relations sebagai penyampai informasi kepada public tercapai, ada hubungan harmonis suatu organisasi dengan masyarakat (Chatamallah, 2008). Dalam penelitian Gifari and Purnama (2017) ditemukan banyak manfaat dari media relations yang berhubungan dengan teori dari tujuan public relations. Pertama menumbuhkembangkan citra yang positif untuk public eksternal, kedua mendorong tercapainya saling pengertian antara publik sasaran dengan perusahaan, ketiga mengembangkan sinergi fungsi pemasaran dengan public relations. Media relations adalah aktivitas komunikasi untuk menjalin pengertian dan hubungan baik dengan media massa dalam rangka pencapaian publikasi organisasi yang maksimal serta berimbang (balance) (Febriandi, 2017).

Salah satu kegiatan perusahaan dalam memberikan informasi kepada public atau masyarakat untuk memperoleh dukungan dan kepercayaan publik adalah kegiatan media relations. Media relations adalah aktivitas komunikasi public relations/humas untuk menjalin pengertian dan hubungan baik dengan media massa dalam rangka pencapaian publikasi organisasi yang maksimal serta berimbang (Wardhani, 2008). Public relation dan media relation menunjukan kerja sama yang baik seperti untuk membangun Citra Positif Hotel Grand Clarion Kendari dalam kerja sama tersebut bukan hanya menyangkut pada lingkup professional akan tetapi sampai kepada tahap personal. Cara yang digunakan adalah membangin hubungan antara public relations dan media relations adalah pendekatan sistematis dan bijaksana. Public Relations harus berusaha untuk selalu mengembangkan hubungan interpersonal dengan media relation (Seniwati, 2016).

Jefkins menjalankan prinsipprinsip umum untuk membina hubungan media yang baik sebagai berikut (Ardianto, 2011);

a. By serving the media (memahami dan melayani media), yaitu memberikan pelayanan kepada media.

b. By establishing a reputations for reliability (membangun reputasi sebagai orang yang dapat dipercaya). Yaitu menegakan suatu reputasi agar dapat dipercaya.

c. By supplying good copy (menyediakan salinan yang baik). Yaitu memasukan naska informasi yang baik.

d. By cooperations in providing material (bekerjasama dalam penyedian materi). Yaitu melakukan kerja sama yang baik dalam menyediakan bahan atau informasi.

e. By providing verification facilities (menyediakan fasilitas verivikasi). Yaitu penyediakan fasilitas yang memadai.

f. By building personal relationship white the media 
(membangun hubungan personal yang kokoh). Yaitu membangun hubungan secara personal dengan media

Dalam penelitian Febriandi (2017), aktivitas media relations yang telah dilakukan adalah penulisan press release, special event, press tour, konferensi pers, press interview, press briefing, dan press luncheon. Dari paparan tersebut diketahui disimpulkan bahwa strategi public relation mempunyai peran yang sangat penting dalam membangun media relation. Dengan demikian, penyebaran informasi dapat tersampaikan kepada publik. Dalam penelitian ini, keberadaan media relations dikaitkan dengan cara dari komunikasi public relations untuk menyebarkan informasi pariwisata Indonesia.

\section{Metodologi Penelitian}

Penelitian ini menggunakan metode kualitatif deskriptif. Seperti yang dikatakan oleh Ary et al. (2010) bahwa penelitian kualitatif merujuk pada kajian tentang fenomena sosial atau fakta-fakta yang terjadi di lapangan. Oleh karena itu, proses pengumpulan data dilakukan melalui kajian pustaka dan dokumen. Data primer adalah dokumen yang diambil dari website Kementerian Pariwisata dan Ekonomi Kreatif Indonesia yang berkaitan dengan strategi public relations atau strategi membangin hubungan masyarakat dalam media. Data sekunder diambil dari jurnal- jurnal dan kajian pustaka atau berita yang berkaitan dengan media relation untuk publikasi pariwisata Indonesia.

Data yang diperoleh dianalisis menggunakan beberapa tahapan seperti yang diungkapkan oleh (Miles and Huberman, 1992) yaitu tahap reduksi data, penyajian data, dan penarikan simpulan. Data yang diperoleh dikategorikan sesuai dengan kebutuhan kajian penelitian dan disederhanakan sesuai kebutuhan. Kemudian, dilanjutkan pada pemaparan data yang disesuaikan dengan fokus penelitian dan dianalisis. Tahap terakhir melakukan penentuan simpulan.

\section{Hasil}

Hasil analisis dokumen diketahui bahwa implementasi strategi public relation dari media yang digunakan untuk meningkatkan daya tarik parisiwata. Berikut hasil temuan;

Tabel 1. Implementasi Strategi Media

\begin{tabular}{|c|c|}
\hline POP & POSE \\
\hline \multirow[b]{2}{*}{ Pre-event } & $\begin{array}{lll}\text { Paid } & \text { Media: } & \text { MNC, }\end{array}$ \\
\hline & $\begin{array}{l}\text { TRANSMEDIA, TEMPOMEDIA } \\
\text { GROUP, KOMPAS }\end{array}$ \\
\hline \multirow[t]{3}{*}{ On-event } & Owned Media: \\
\hline & www.kemenpar.go.ig, Ragam \\
\hline & $\begin{array}{l}\text { Pesona, Pesona E-Magazine, } \\
\text { Videotron }\end{array}$ \\
\hline \multirow[t]{7}{*}{ Post-event } & Social Media: \\
\hline & Instagram (@ Kemenpar), \\
\hline & FanspageFacebook (Kementerian \\
\hline & Pariwisata), \\
\hline & Twitter (@Kemenpar_RI), \\
\hline & Youtube(Kementerian Pariwisata) \\
\hline & $\begin{array}{l}\text { Endorser: Testimoni social media } \\
\text { enthusiasts (Wonderful Noon) }\end{array}$ \\
\hline Sumber: & 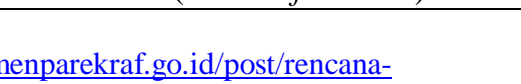 \\
\hline
\end{tabular}


146 JMK (Jurnal Manajemen dan Kewirausahaan) 5 (2) 2020,140-154

Dari tabel 1 diketahui bahwa ada dua strategi public relations dalam membangun media relations yaitu POP dan POSE. Berikut tampilan dari POSE yang telah dibangun oleh pemerintah Indonesia:

\section{Instragram}

kemenpar $\checkmark$
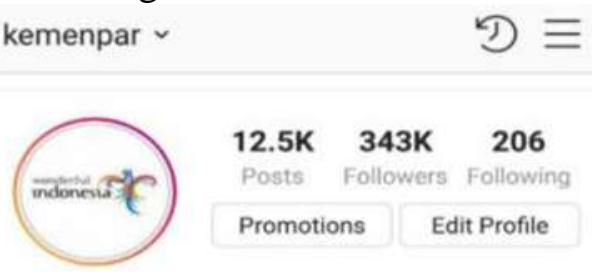

\subsection{K 343K 206}

Posts Followers Following

Promotions Edit Profile

\section{Kementerian Pariwisata 0}

Government Organization

Akun Instagram Resmi Kementerian Pariwisata RI Dikelola oleh Biro Komunikasi Publik Kement. more youtube.com/humaskemenpar

Gedung Sapta Pesona Kemenpar Jl. Medan Merdeka

Barat No17, Jakarta, Indonesia 10110

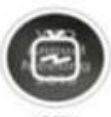

IGTV
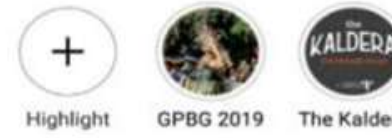

GPBG 2019

\section{Email}

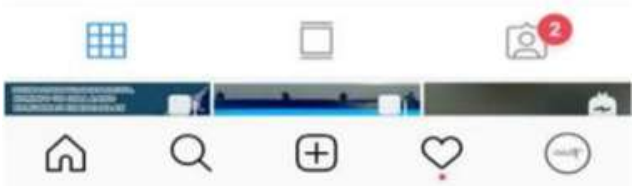

Gambar 1. Tampilan Instagram Kemenpar

Sumber:

http://www.kemenparekraf.go.id/post/rencanastrategis-2015-2019-kementerian-pariwisata

\section{Twitter}

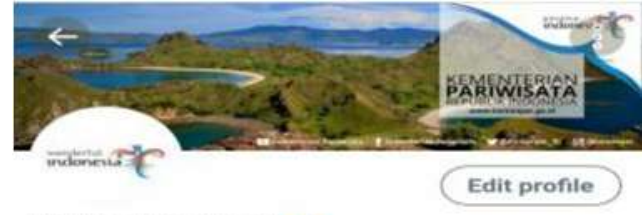

\section{KEMENPAR RI *}

Akun Twitter Resmi Kementerian Pariwisata

Republik Indonesia. Dikelola oleh Biro

Komunikasi Publik Kementerian Pariwisata.

"Wonderfullindonesia \#Pesonalndonesia

- Jakarta Pusat, DKI Jakarta

Q kemenpar.go.id Joined June 2015

567 Following 102K Followers

Tweets Tweets \& replies Media Likes
7
Pinned Tweet
KEMENPAR RIO @Kemenpar.... 14h

KEMENPAR RI O@Kemenpar.. 14h Halo "ISobatWisata, Mau tahu keseruan dan Nagita..? Ngobrolin apa ya ki mereka..? Penasaran..?

Gambar 2. Tampilan Twitter Kemenpar

Sumber:

http://www.kemenparekraf.go.id/post/rencanastrategis-2015-2019-kementerian-pariwisata

\section{FanPage}

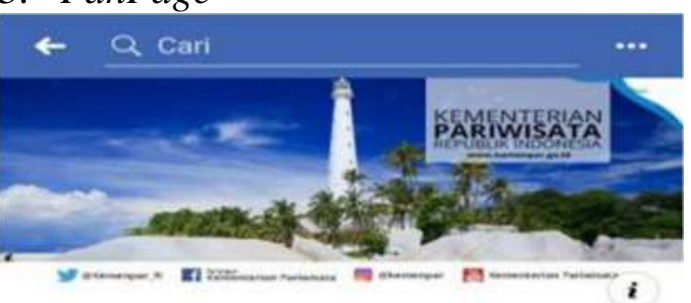

atf Kementerian Pariwisata 0

a cuemenpar

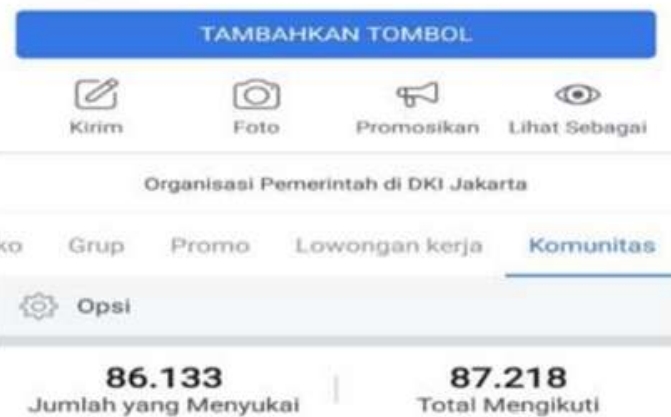

Gambar 3. Tampilan Fanpage

Kemenpar

Sumber:

http://www.kemenparekraf.go.id/post/rencanastrategis-2015-2019-kementerian-pariwisata 
4. YouTube

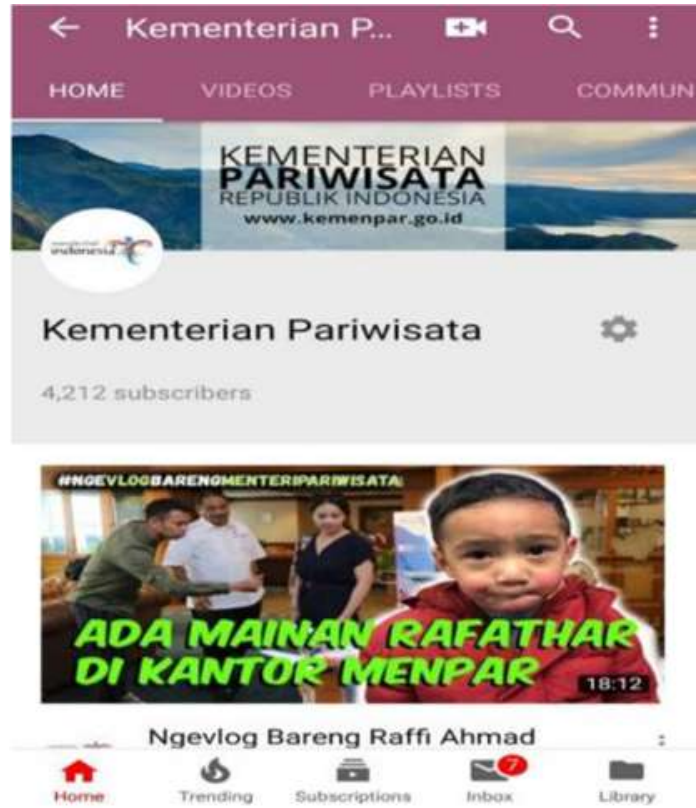

Gambar 4. Tampilan YouTube Kemenpar

Sumber:

http://www.kemenparekraf.go.id/post/rencanastrategis-2015-2019-kementerian-pariwisata

\section{E-Magazine}
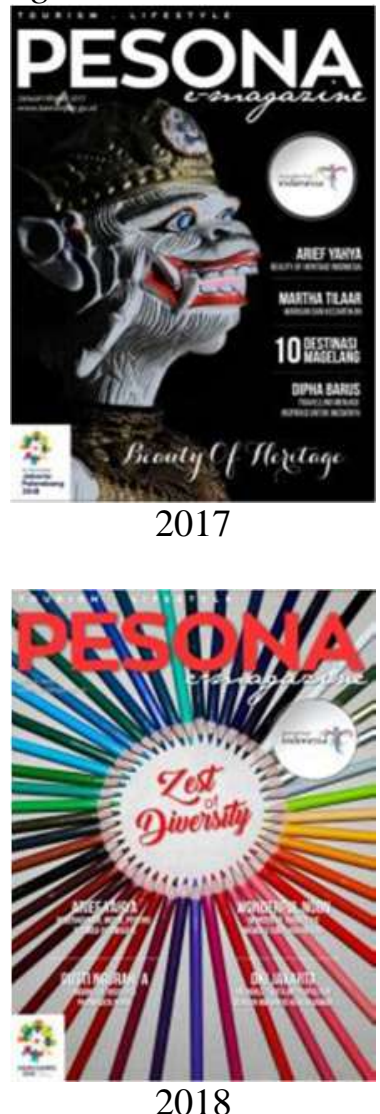


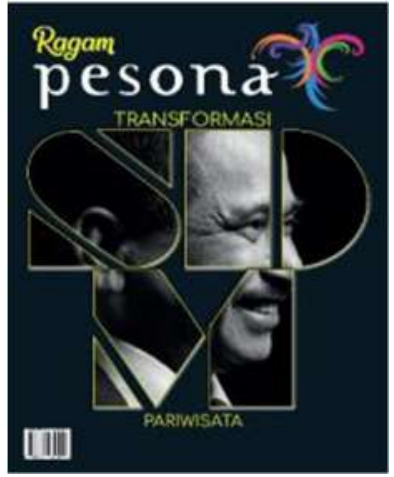

2019

Gambar 6. Tampilan Majalah Ragam Pesona

Sumber:

http://www.kemenparekraf.go.id/post/rencanastrategis-2015-2019-kementerian-pariwisata

\section{Website Kemenpar}

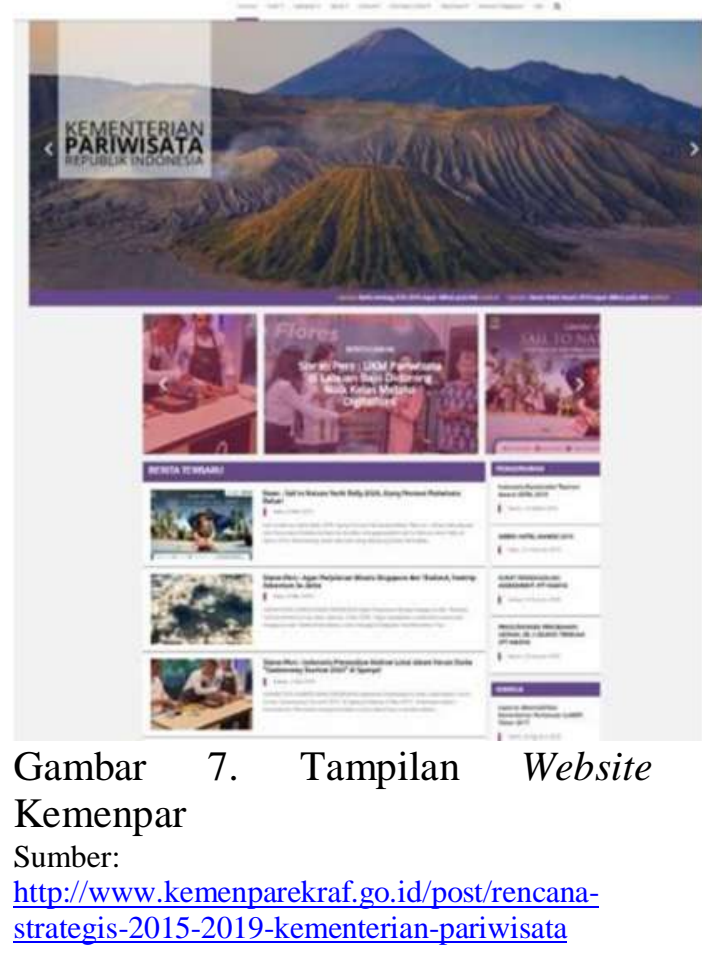

\section{Videotron}

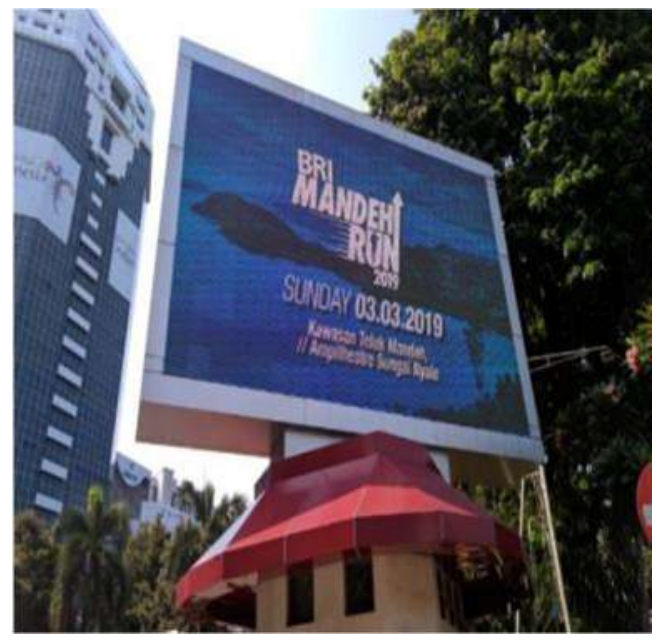

Gambar 8. Tampilan Videotron Sumber:

http://www.kemenparekraf.go.id/post/rencanastrategis-2015-2019-kementerian-pariwisata

\section{Digital Banner}

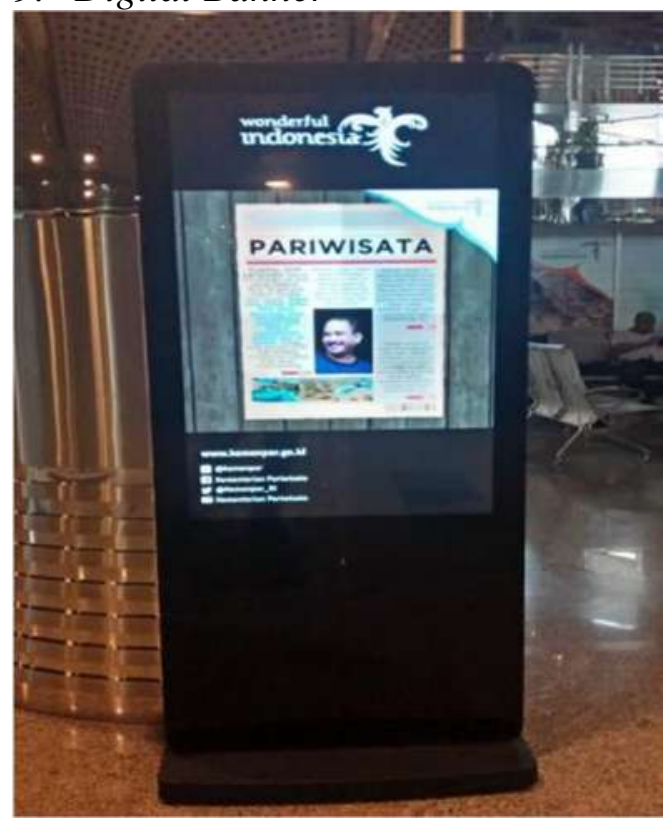

Gambar 9. Tampilan Digital Banner Promosi Pariwisata

Sumber:

http://www.kemenparekraf.go.id/post/rencanastrategis-2015-2019-kementerian-pariwisata 
10. Layanan Informasi Bank Data

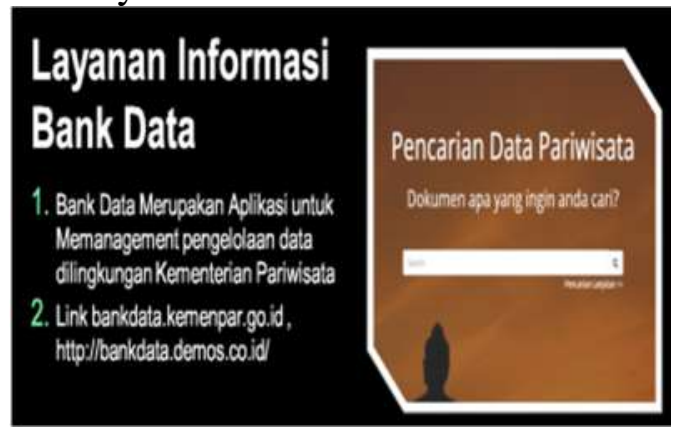

Gambar 10. Tampilan Layanan Informasi

Sumber:

http://www.kemenparekraf.go.id/post/rencanastrategis-2015-2019-kementerian-pariwisata

11. Layanan Pengaduan Halo

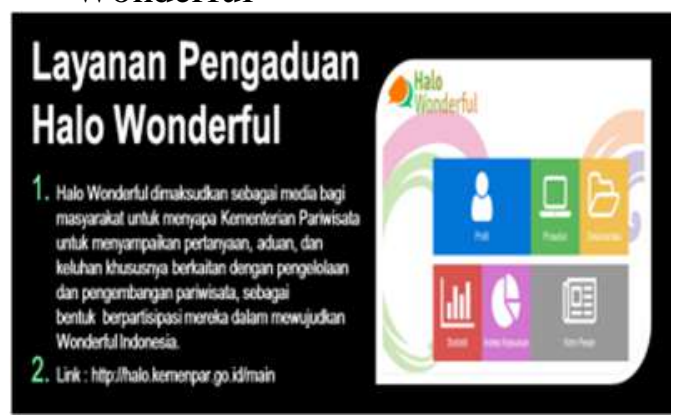

Gambar 11. Tampilan Layanan Pengaduan

Sumber:

http://www.kemenparekraf.go.id/post/rencanastrategis-2015-2019-kementerian-pariwisata

12. Pejabat Pengelola Informasi dan Dokumentasi (PPID)
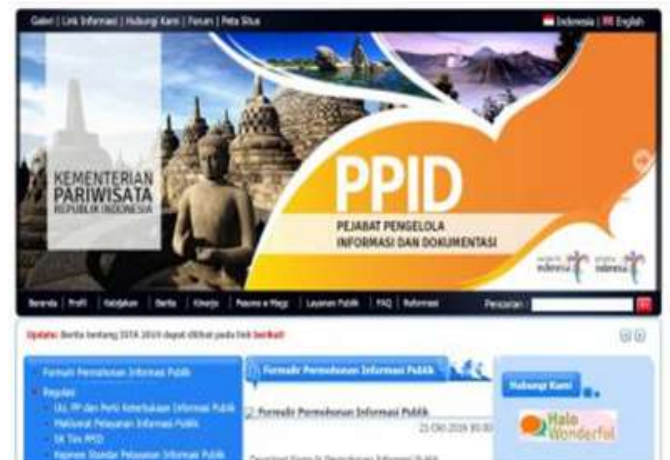

Gambar 12. Tampilan PPID

Pariwisata

Sumber:

http://www.kemenparekraf.go.id/post/rencanastrategis-2015-2019-kementerian-pariwisata

\section{Wonderful Noon}

Melalui Kegiatan Off -Air Media Sosial Kemenpar Yang Melibatkan Komunitas
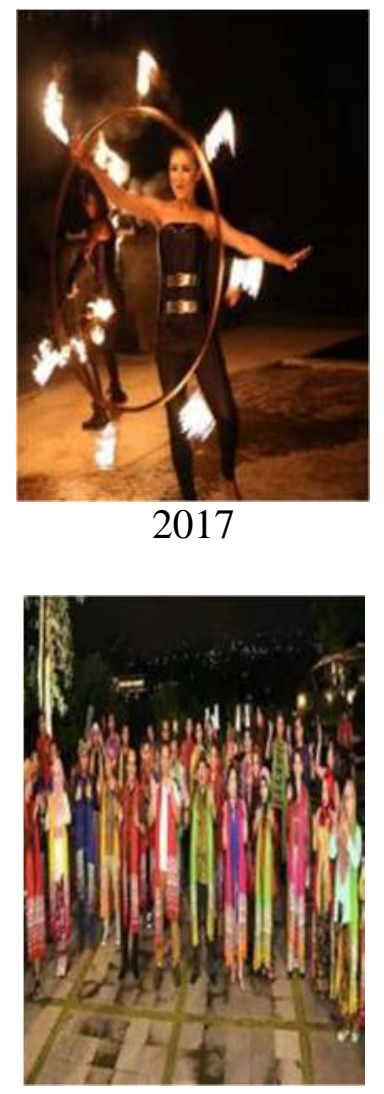

\section{8}

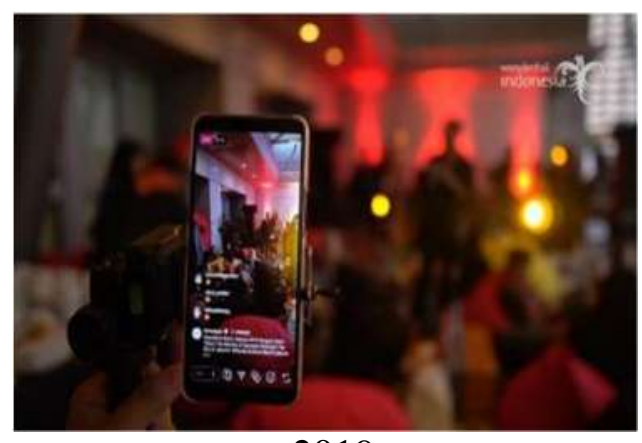

2019

Gambar 13. Foto Kegiatan Off-Air Pariwisata

Sumber:

http://www.kemenparekraf.go.id/post/rencanastrategis-2015-2019-kementerian-pariwisata

\section{Pembahasan}

Strategi media public relations telah dilakukan dengan sangat matang 
oleh pemerintah Indonesia. Berbagai media yang telah digunakan cukup efektif meningkatkan minat wisatawan. Dari dua media POP dan POSE telah berhasil meraih prestasi antara lain;

1. Pesona E-Magazine telah meraih juara 1 kategori Media Internal pada ajang Anugerah Media Humas $\quad($ AMH $) \quad 2017 \quad$ di Pelambang, Juara 1 Kategori Media Internal Sub Kategori $E$ Magazine pada ajang Public Relations Indonesia Awards (PRIA) 2018 di Surabaya, JawaTimur.dan Gold Winner dalam Kategori E-Magazine pada Sub Kategori Kementerian yang dimenangkan oleh majalah electronic Pesona E-Magazine Edisi II Tahun 2018 dalam acara PR Indonesia Awards (PRIA) 2019.

2. Media sosial yang telah digunakan mendapatkan penghargaan Silver Winner dalam Kategori Media Sosial pada Sub Kategori Kementerian dalam acara PR Indonesia Awards (PRIA) 2019

3. Ragam pesona mendapatkan penghargaan Silver Winner dalam Kategori Kementerian.

Dari berbagai penghargaan yang telah diperoleh oleh Kementerian Pariwisata dan Ekonomi Kreatif dari media yang diterapkan, maka pemerintah melalui Kementerian Pariwisata dan Ekonomi Kreatif telah dinilai berhasil menerapkan Sistem Pemerintahan
Berbasis Elektornik (SPBE). Apalagi era saat ini, semua aktivitas manusia telah dipermudah melalui proses digitalisasi. Dalam dunia pariwisata, setiap orang dengan sangat mudah dapat mengetahui destinasi wisata yang menarik beserta biaya perjalanan. Hal ini dapat diakses atau diperoleh melalui media sosial. Oleh karena itu, media sosial sangat memiliki dampak yang besar terhadap kemajuan pariwisata di Indonesia. Dampak dari jaringan secara digital (Media Sosial) meningkatkan kompleksitas dinamika perilaku dalam ekosistem yang kompleks, dan bagaimana informasi dan Media Sosial dapat digunakan untuk mengatasi tantangan manajerial baru yang ditimbulkan oleh meningkatnya kompleksitas digital (Martín-Rojas et al., 2020).

Meskipun penggabungan besar-besaran media sosial ke dalam strategi komunikasi, masih banyak yang kita tidak tahu tentang jenis konten yang diharapkan akan diterima oleh para pemangku kepentingan dan percakapan apa yang ingin mereka lakukan dengan organisasi (Navarro, Moreno and Al-Sumait, 2017). Walaupun demikian, media sosial tetap dinilai memiliki pengaruh yang cukup efektif dalam merubah pola promosi suatu produk pariwisata. Media sosial mungkin mewakili inovasi / revolusi sosial terbesar dalam sejarah komunikasi, secara mendasar mengubah cara manusia berkomunikasi, dan praktik hubungan masyarakat, jurnalisme, periklanan, 
pemasaran, dan bisnis. Media sosial mewakili paradigma komunikasi baru dalam public relations (Kent and $\mathrm{Li}$, 2019).

Oleh karena itu, media memainkan peran sentral dalam memberi informasi kepada publik tentang apa yang terjadi di dunia, khususnya di wilayah-wilayah di mana audiens tidak memiliki pengetahuan atau pengalaman langsung. Media membentuk debat publik dengan sangat baik (Happer, Philo and Philo, 2013). Media digital sebagai sumber daya informasi dan platform komunikasi untuk wisatawan telah tumbuh secara signifikan. Selain memfasilitasi mobilitas dan interaktivitas, media digital juga telah berperan dalam membuat konvergensi menjadi kenyataan. Konvergensi di media dapat dengan mudah diamati di situs web pariwisata. Desain situs web pariwisata dapat memberikan pengalaman virtual bagi wisatawan tentang suatu destinasi, dan dapat memengaruhi pembentukan citra destinasi pariwisata di benak mereka. Manajemen citra dan persepsi gambar merupakan inti dari pariwisata yang disebabkan oleh media (Divinagracia, Divinagracia and Divinagracia, 2012).

Dari pemahaman tersebut, pemerintah dengan sangat jelas memanfaatkan fungsi dan peran dari media. Konsep penyatuan media relations yang terwujud dalam komunikasi public relations. Pemerintah membentuk opini dari public melalui informasi yang dibagikan di media sosial tentang pariwisata Indonesia, sehingga banyak kepercayaan masyarakat terhadap keindahan destinasi wisata Indonesia yang memuaskan.

\section{Simpulan}

Hasil analisis data disimpulkan bahwa pemerintah melalui Kementerian Pariwisata dan Ekonomi Kreatif telah memanfaatkan dengan sangat praktis dari strategi public relations. Selain itu, pemerintah telah menerapkan strategi tersebut untuk mengimplementasikan media relations sebagai wujud konsep komunikasi suatu organisasi dengan publik atau masyarakat. Kementerian Pariwisata dan Ekonomi Kreatif telah menggunakan dua strategi dalam mengimplementasikan media yaitu POP yang berkaitan membangun berbagai macam event atau acara dalam rangka memperkenalkan obyek wisata di Indonesia. Sedangkan untuk strategi media POSE melibatkan media massa, media elektronik dan media sosial. Dari berbagai strategi tersebut, Kementerian Pariwisata dan Ekonomi Kreatif telah mendapatkan berbagai macam penghargaan pada tahun 2018 dan 2019. Selain itu, wisata di Indonesia juga lebih banyak diminati karena keragaman dan kekhasan wisata di Indonesia.

Dampak dari hasil penelitian ini adalah 1) Kementerian Pariwisata dan Ekonomi Kreatif harus terus memperbarui informasi tempat- 
tempat wisata di Indonesia yang telah diperbaharui, 2) peningkatan promosi ataupun penyebaran informasi tentang keindahan wisata Indonesia bagi wisatawan dalam negeri dan luar negeri, 3) media pemicu bagi Kementerian Pariwisata dan Ekonomi Kreatif dalam rangka meningkatkan kualitas sector wisata di Indonesia.

\section{Daftar Pustaka}

Achsa, A., Destiningsih, R. and

Hirawati, H. (2020)

'Strategi Pemasaran

Untuk Meningkatkan Daya

Saing Wisata Desa Taman

Bunga Manohara Desa Purwodadi', JMK (Jurnal Manajemen dan

Kewirausahaan), 5(1), pp. 1-17. doi:

10.32503/jmk.v5i1.692.

Ardianto, E. (2011) Dasar-

Dasar Public Relations.

Jakarta: Graha Ilmu.

Ary, D. et al. (2010) Introduction to Research in Education. 8 Edition. CA: Cengage Learning.

Chatamallah, M. (2008) 'Strategi "Public

Relations" dalam promosi

Pariwisata: Studi Kasus dengan Pendekatan "Marketing Public Relations" di Provinsi Banten', Mediator, 9(2).

Divinagracia, $\mathrm{L}$.

A.,

Divinagracia, M. R. G. and Divinagracia, D. G. (2012) 'Digital MediaInduced Tourism: The Case of Nature-based Tourism (NBT) at East Java, Indonesia', Procedia - Social and Behavioral Sciences. Elsevier, 57, pp. 85-94. doi:

10.1016/J.SBSPRO.2012. 09.1161.

Febriandi (2017) 'Analisis Media Relations Dalam Mempromosikan

Pariwisata Daerah Di Dinas Pariwisata Kabupaten Kutai Kartanegara', eJournal Ilmu Komunikasi, 5(2), pp. 24-38.

Gifari, F. and Purnama, H. (2017) 'Strategi Asiapr Dalam Memperkuat Hubungan Media Dengan Forum

Wartawan

Otomotif (FORWOT)', PRofesi Humas: Jurnal Ilmiah Ilmu Hubungan Masyarakat, 1(2).

Hafizah, E. (2015) 'Strategi Public Relations Dalam Membangun Hubungan Dengan Media', $A l$ Hikmah, 8(2). doi: 10.24260/alhikmah.v8i2.80.

Happer, C., Philo, G. and Philo, G. (2013) 'The Role of the Media in the 
Construction of Public Belief and Social Change', Journal of Social and Political Psychology, 1(1), pp. 321-336. doi: 10.5964/jspp.v1i1.96.

Hermawan, E. (2019) 'Strategi Kementerian Pariwisata Indonesia Dalam Meningkatkan Branding Wisata Halal', Referensi : Jurnal Ilmu Manajemen dan Akuntansi, 7(2), pp. 87-95. doi:

10.33366/REF.V7I2.1512 .1

Ilievska, A. Z. (2018) 'PUBLIC RELATIONS

MANAGEMENT IN THE TOURISM INDUSTRY: NEEDS AND PERSPECTIVES', International Journal of Research in Humanities, Arts and Literature, 6(4).

Kent, M. L. and Li, C. (2019) 'Toward a normative social media theory for public relations', Public Relations Review. JAI, p. 101857. doi: 10.1016/J.PUBREV.2019 .101857 .

Martín-Rojas, R. et al. (2020) 'Social Media Use and the Challenge of Complexity: Evidence from the Technology Sector', Journal of
Business Research.

Elsevier. doi:

10.1016/J.JBUSRES.2019 .12 .026 .

Miles and Huberman (1992) Analisis Data Kualitatif. Jakarta: Universitas Indonesia Press.

Navarro, C., Moreno, A. and AlSumait, F. (2017) 'Social media expectations between public relations professionals and their stakeholders: Results of the ComGap study in Spain', Public Relations Review. JAI, 43(4), pp. 700-708. doi: 10.1016/J.PUBREV.2016 .12 .008 .

Putra, K. D. C. (2008) 'Strategi Public Relations Pariwisata Bali', Jurnal ILMU KOMUNIKASI, $5(1)$.

Seniwati, S. (2016) 'Peran Public Relation Dan Media Relation Dalam Membangun Citra Positif Hotel Grand Clarion Kendari', Jurnal Ilmu Komunikasi UHO : Jurnal Penelitian Kajian Ilmu Komunikasi dan Informasi, 1(2). Available at:

http://ojs.uho.ac.id/index. php/KOMUNIKASI/articl e/view/1455 (Accessed: 5 March 2020).। 
Soleh, S. and Elvinaro, A. (2003) Dasar-dasar Public Relations. Bandung: PT. Remaja Rosdakarya Offset.

Solihah, A. W., Musiasa, I. N. and Shihab, M. (2018) 'Aktivitas Public Relations Pengelola Situs Pariwisata Tanjung Lesung Untuk Meningkatkan Jumlah Wisatawan', Jurnal Komunikasi Global, 7(1), pp. 42-52. doi: 10.24815/jkg.v7i1.10528.

Wardhani, D. (2008) Media

Relations - Sarana Membangun Reputasi

Perusahaan. Yogyakarta:

Graha Ilmu.

Wiratmo, L. B., Irfan, N. and Kuwatono (2017) 'Website Pemerintah Daerah Sebagai Sarana Online Public Relations', Jurnal Aspikom, 3(2).

www. kemenpar.go.id 